\title{
TRADISI MERARIQ PADA MASYARAKAT DESA BATUNYALA LOMBOK TENGAH
}

\author{
Deviana Mayasari, S.Pd.,M.Si
}

\section{INFO ARTIKEL}

\section{Riwayat Artikel:}

Diterima: 09-09-2016

Disetujui: $30-09-2016$

\section{Kata Kunci:}

Tradisi Merariq, Adat Istiadat Lombok.

\section{A. LATAR BELAKANG}

Masyarakat Indonesia merupakan masyarakat yang majemuk yang terdiri dari ribuan pulau-pulau dimana masing-masing penduduk dan suku bangsa yang mendiaminya dan memiliki tradisi dan keyakinan yang

\begin{abstract}
Abstrak: Masyarakat memandang tradisi merariq ini sebagai sebuah warisan yang harus mereka jaga dan lestarikan, karena di dalamnya mengandung makna yang menurut mereka patut untuk dipertahankan, meski sudah mengalami sedikit pergeseran di dalam tata caranya, akan tetapi tradisi ini tetap dijalankan oleh masyarakat. Hal inilah yang menarik untuk diteliti dari merariq yaitu bagaimana konsep tata cara dalam adat merariq yang dapat mengatur sedemikian rupa konsep berpikir masyarakat untuk masih mempertahankan adat merariq.

Fokus dalam penelitian ini bagaimana prosesi pelaksanaan adat merariq, apa makna adat merariq bagi masyarakat Batunyala dan apa yang menyebabkan tradisi ini masih dilakukan oleh warga masyarakat yang ada di desa Batunyala. Metode yang digunakan dalam penelitian ini adalah metode kualitatif dengan jenis deskriptif, yang menggambarkan atau menjelaskan fenomena sosial yang terjadi di tempat penelitian. Tekhnik pengumpulan data yang dilakukan yaitu melalui observasi, wawancara dan dokumentasi.

Adapun hasil penelitian yang didapatkan yaitu adapun prosesi pelaksanaan dalam adat merariq yang dimulai dari melakukan merariq, sejati/selabar, mbait wali,nikahang, mbait janji, sorong serah, nyongkolan dan yang terakhir dilakukan dengan upacara balik lampak nae. Tradisi merariq mempunyai berbagai macam makna yaitu: mempunyai nilai untuk mengistimewakan perempuan, memiliki pesan sosial, memiliki pesan untuk saling menghargai dan bersyukur, memiliki pesan untuk mendidik, memiliki pesan moral, menunjukkan sikap pemberani dan betanggung jawab. Kemudian dalam penelitian ini adapun yang menyebabkan masyarakat di desa Batunyala masih melakukan tradisi merariq sampai sekarang yaitu karena : (1) Faktor adat, (2) Faktor Orang tua, (3) Faktor Agama, (4) Faktor Ekonomi (biaya), dan (5) Faktor kemauan dari yang perempuan.
\end{abstract}

ABSTRAK

Abstract : The communities regard this tradition as an heritage from ancestor that must be kept and preserved, because in this culture there is point must be keeping, so the younger's in this village follow up this merariq tradition, although have been moving in this custom a little, but this tradition keep moving by the society. This is special thing that interesting to get research from merariq tradition that is how the custom concept organizing the community thinking concept to preserving and receiving merariq compared with the developing situation now.

The focus in this research is how the custom or tradition of merariq is done, what is the meaning of custom of merariq by Batunyala's communities and what caused this tradition have been doing by Batunyala's communities.. The method is used in this research is qualitative and using descriptive type to describe the social phenomena is happened in the site of research. The data collecting technique's are used like observation, interview, and documentation.

The results of this research are got is the ceremonials of custom of merariq are started with doing merariq, sejati/selabar, mbait wali, nikahang mbait janji, sorong serah, nyongkolan, and the last is balik lampak nae ceremony by community. The merariq tradition have much meaning that is: merariq have the value to make special for woman, have social messages, have messages to respect one another and grateful to god, have message to educate, and moral messages, merariq is the way to show brave and responsibility attitudes. And then, in this research, the communities factors are cause the preserving of merariq tradition are: 1) custom factors, 2) parent factors, 3) religion factors, 4) economic factors (fee), and 5) willing factors from the woman. 
Di pulau Lombok banyak macam-macam upacara adat yang dilaksanakan dan khususnya di Lombok Tengah yang masih sangat dominan akan pelaksanaannya yaitu adat perkawinan, dimana sebagian besar masyarakat masih menerima adat merariq karena dianggap untuk melestarikan budaya, dan dalam tradisi merariq ini terdapat begitu banyak prosesi dan ritual yang mencerminkan keistimewaan dari tradisi itu sendiri. Bagi masyarakat sasak merariq tidak dianggap negatif karena dianggap sebagai usaha untuk melestarikan budaya dan menjalankan adat istiadat yang sudah dimana tindakan merariq ini diawali dengan membawa lari calon mempelai perempuan oleh calon mempelai laki-laki secara diam-diam keluar dari rumahnya dan tanpa sepengetahuan orang tua dari yang perempuan, kemudian proses ini akan diakhiri dengan rembuk antara keluarga kedua calon mempelai setelah berlangsungnya atau terjadinya merariq yang dilakukan oleh kedua calon mempelai tersebut ada bahwa dengan terjadinya suatu perkawinan, tindakan tersebut merupakan tindakan yang sudah umum dilakukan oleh masyarakat dan dibenarkan secara adat, sebaliknya tindakan melamar seorang gadis tidak digunakan karena kegiatan melamar dianggap dengan "meminta" yang diartikan sama dengan "meminta anak ayam", sehingga tindakan tersebut dianggap tidak sopan oleh orang tua dari pihak yang perempuan.

Di tengah perkembangan zaman yang semakin modern ini adat merariq masih terus dilakukan oleh masyarakat dan khususnya di Lombok Tengah di desa Batunyala. Masyarakat Batunyala sangat memegang teguh tradisi tersebut sampai sekarang meski terdapat perbedaan dengan merariq di zaman dahulu akan tetapi upacara-upacara yang dilakukan dalam adat merariq masih dilakukan oleh masyarakat hanya yang berbeda tata cara di dalam melakukan merariq itu saja. Hal inilah yang menarik untuk diteliti dari merariq ini yaitu bagaimana konsep tata cara dalam adat merariq yang dapat mengatur sedemikian rupa konsep berpikir masyarakat untuk masih mempertahankan dan menerima merariq dibandingkan dengan keadaan sekarang yang serba maju.

Berdasarkan uraian tersebut di atas maka peneliti tertarik untuk mengadakan penelitian dengan judul “ Tradisi Merariq Pada Masyarakat Desa Batunyala Lombok Tengah"

\section{B. METODE PENELITIAN}

\section{Pendekatan Penelitian}

Dalam penelitian ini, yang digunakan adalah pendekatan penelitian kualitatif dengan jenis deskriptif yaitu menggambarkan atau menjelaskan fenomena sosial yang terjadi di tempat penelitian. Bodgan dan Taylor mendefinisikan penelitian kualitatif sebagai prosedur penelitian yang kmenghasilkan data deskriptif berupaka kata-kata tertulis atau lisan dari orang-orang dan perilaku yang dapat diminati. Jadi dalam penelitian ini menggunakan metode deskriptif kualitatif, yaitu suatu metode yang secara keseluruhan memanfaatkan cara-cara penafsiran dengan menyajikannya dalam bentuk deskripsi.

\section{Lokasi Penelitian}

Penelitian ini dilakukan di Desa Batunyala Kecamatan Praya Tengah Kabupaten Lombok Tengah.
Penentuan lokasi penelitian ini juga tentunya dengan adanya pertimbangan yaitu dibandingkan dengan desadesa yang lainnya di desa Batunyala ini sampai sekarang masih sangat kuat dengan tradisi merariq.

\section{Subyek dan Informan Penelitian}

Dalam penelitian ini peneliti menggunakan beberapa subyek dan informan penelitian.

\section{1) Subyek}

Adapun subyek dalam penelitian ini yaitu orang yang mengetahui tentang tradisi merariq dan terlibat langsung dalam upacara tersebut. Dan yang menjadi subyek dalam penelitian ini adalah :

(a) Lalu Darmawe (Papuq Zan) selaku tokoh adat di desa Batunyala

(b) Supriyadi selaku pembayun dalam proses adat merariq

(c) Amaq Man (Suhaili) yaitu salah satu orang tua dari perempuan

(d) Bapak H.Rohan (salah satu orang tua dari laki-laki)

(e) Sri Sujayanti (Pelaku merariq)

(f) Aditya Juniarahman (pelaku merariq)

(g) Dedy Sukarnayadi (pelaku merariq)

(h) Wira (pelaku merariq)

\section{2) Informan}

Informan yaitu orang-orang yang bisa dijadikan sebagai sumber informasi untuk memperoleh data dengan menggunakan tekhnik wawancara. Informan yang dipilih yaitu warga masyarakat yang memahami tentang tradisi merariq dan tidak harus terlibat secara langsung dalam kegiatan tersebut tetapi mereka yang memiliki wawasan cukup luas tentang tradisi merariq. Kemudian yang peneliti ambil sebagai informan dalam penelitian ini adalah :
(a) Bapak Ir. Haryanto selaku Kepala Desa di Batunyala
(b) Parlan (Amaq Sudir) selaku Kepala Dusun di Kongkang desa Batunyala
(c) Bapak H. Ridwan selaku tokoh agama di desa Batunyala
(d) Fathurrahman (Penjual pupuk di desa Batunyala)

\section{Sumber Data}

Sumber data yag digunakan untuk menyediakan informasi terdapat dua sumber yaitu data primer dan data sekunder :

\section{1) Data Primer}

Data primer adalah data yang bersumber dari informan yang mengetahui secara jelas dan rinci mengenai masalah yang sedang diteliti. Kata-kata atau ucapan lisan dan perilaku manusia merupakan data utama atau data primer dalam suatu penelitian ( Arikunto,2002). Data diperoleh secara langsung dari hasil observasi dan wawancara dengan para pelaku merariq yakni bagaimana proses ketika mereka melakukan merariq. Selain itu, untuk mendukung data hasil penelitian penulis juga melakukan wawancara terhadap kepala desa dan kepala dusun tentang pendapat mereka mengenai tradisi yang masih dilakukan oleh masyarakat di desa Batunyala.

2) Data Sekunder

Data sekunder adalah data sebagai pelengkap data primer. Sumber data sekunder dalam 
penelitian ini adalah data yang diperoleh dari catatan, arsip atau dokumen yaitu data berupa profil desa Batunyala yaitu letak geografis desa, tingkat pendidikan, dan mata pencaharian penduduk di desa Batunyala. Sumber data juga diperoleh dari buku-buku yang berkaitan dengan tradisi masyarakat Lombok. yang berkaitan dengan tradisi merariq di masyarakat desa Batunyala.

\section{Tekhnik Pengumpulan Data}

Data adalah segala fakta dan angka yang dapat dijadikan bahan untuk menyusun suatu keperluan (Arikunto 1987 :91). Untuk mengumpulkan data yang akurat dan menangkap semua fenomena objek penelitian, maka dalam penelitian ini peneliti menggunakan tekhnik pengumpulan data sebagai berikut :

1) Observasi

Menurut Patton (dalam Sugiyono, 2010: 226) observasi lebih mampu memahami konteks data dalam keseluruhan situasi sosial, jadi akan diperoleh pandangan yang menyeluruh.

Observasi yang dilakukan adalah observasi tidak terstruktur, hal ini dimaksudkan agar pengambilan data atau fakta-fakta sosial kaitannya dengan fokus penelitian tidak terikat dengan panduan yang dibuat oleh peneliti.

Dalam penelitian ini pengamatan dilakukan untuk mengetahui kondisi sosial dan keagamaan di desa Batunyala, kemudian dilanjutkan dengan melakukan silaturahmi ke tempat kediaman subjek (tokoh adat, tokoh agama, pembayun, orang tua, dan pemuda yang melakukan merariq) atau dengan memperoleh informasi dari para informan (kepala desa, kepala dusun, dan warga yang menyambut positif tradisi tersebut) mengenai tradisi merariq. Silaturahmi ini dilakukan agar peneliti lebih akrab dan bisa datang kembali apabila ada yang belum jelas atau ada yang perlu ditanyakan lagi mengenai data yang diperoleh.

2) Wawancara

Wawancara adalah percakapan yang dilakukan oleh dua pihak yaitu pewawancara mengajukan pertanyaan dan yang diwawancarai memberikan jawaban atas pertanyaan tersebut (Moleong, 2000 : 135). Tekhnik wawancara yang dilakukan tidak terstruktur (terbuka, bicara apa saja) namun tetap dalam garis besar yang mengarah terhadap permasalahan penelitian.

Informasi yang ingin didapatkan dengan metode wawancara ini adalah hal-hal yang berkaitan dengan rumusan masalah yang ada yaitu bagaimana proses mereka ketika melakukan merariq, kemudian pandangan mereka tentang makna tradisi merariq, serta apa yang menyebabkan mereka masih melakukan merariq sampai sekarang. Dari daftar pertanyaan tersebut diharapakan mampu menjawab pada fokus permasalahan yang ada.

3) Dokumentasi

Tekhnik dokumentasi merupakan pelengkap dari penggunaan metode observasi dan wawancara dalam penelitian kualitatif. Dokumen bisa berbentuk tulisan, gambar, atau karya-karya dari seseorang. (Sugiyono, 2010: 240).

Metode dokumentasi digunakan untuk mendapatkan data tentang letak geografis, keadaan masyarakat, tingkat pendidikan, mata pencaharian serta sumber lain yang membutuhkan dokumen sebagai pelengkap data seperti gambar, foto-foto saat upacara merariq dilakukan.

\section{Teknik Analisa Data}

Menurut Bogdan (dalam Sugiyono, 2010: 244) Analisis data adalah proses mencari dan dan menyusun secara sistematis data yang diperoleh dari wawancara, catatan lapangan, dan bahanbahan lain, sehingga dapat mudah dipahami dan temuannya dapat diinformasikan kepada orang lain. Adapun komponen dalam analisa data yaitu :

1) Data Reduction (Reduksi data)

Data yang diperoleh dari lapangan jumlahnya cukup banyak, untuk itu perlu dicatat secara rinci. Dalam penelitian ini, reduksi data yang dilakukan yaitu dengan memfokuskan kepada pelaku merariq, yaitu bagaimana proses ketika mereka melakukan merariq.

2) Data Display (Penyajian Data)

Setelah data direduksi, maka langkah selanjutnya adalah mendisplaykan data. Dalam penelitian ini, peneliti menyajikan data dalam bentuk uraian, yang berupa hasil wawancara dengan para subyek dan informan yang berhubungan dengan rumusan masalah yang ada, kemudian melakukan kesimpulan dari data yang didapatkan.

3) Conclusion Drawing (Penarikan Kesimpulan)

Menurut Miles dan Huberman (dalam Sugiyono, 2010:252) Langkah ketiga dalam analisis kualitatif adalah penarikan kesimpulan. Kesimpulan awal yang dikemukakan masih bersifat sementara, dan akan berubah bila tidak ditemukan bukti-bukti yang kuat yang mendukung pada tahap pengumpulan data berikutnya.

\section{DESKRIPSI LOKASI PENELITIAN 1) Kondisi Geografis Desa}

Desa Batunyala ini berkecamatan di Praya Tengah Kabupaten Lombok Tengah. Jarak ke ibu kota kecamatan o km, karena kantor kecamatan praya sendiri terletak di Desa Batunyala, kemudian jarak ke kota Kabupaten yaitu $5 \mathrm{~km}$. Desa Batunyala ini mempunyai luas wilayah 918,51 Ha dan memiliki tanah yang diperuntukkan sebagai lokasi Kantor dan Sekolah 2,1 Ha, kemudian Toko dan Pasar 1,50 Ha, kemudian terminal dan jalan 56, 25 Ha. Desa Batunyala ini memiliki sebelas Dusun yang diantaranya adalah Dusun Kongkang, Tempas, Baru Jale, Tapon, Batu Ngereng, Pegading, Bejeti, Montong Bombong, Gomang, dan Genalu. Desa Batunyala ini berbatasan dengan desa-desa sebagai berikut ; Sebelah Barat berbatasan dengan Desa Gerantung dan Sakra, Sebelah Utara berbatsan dengan Desa beremis dan Gerantung, Sebelah Timur berbatsan dengan Kelebuh, dan Sebelah Selatan berbatasan dengan Desa Lajut dan Pejanggik.

Desa Batunyala memiliki jumlah penduduk sebanyak 6829 jiwa yang terdiri dari jumlah laki-laki sebanyak 2466 jiwa dan jumlah penduduk wanita yaitu 4363 jiwa. Dan jumlah kepala keluaraga 2052 KK. Untuk lebih jelasnya akan penulis paparkan mengenai jumlah penduduk di desa menurut golongan usia dan jenis kelamin. Dalam hal ini bisa dilihat pada Tabel sebagai berikut : 
Tabel 1

Jumlah penduduk menurut golongan Usia dan jenis kelamin

\begin{tabular}{|c|c|c|c|c|}
\hline \multirow{2}{*}{ No } & \multirow{2}{*}{ Golongan Umur } & \multicolumn{2}{|c|}{ Jenis Kelamin } & \multirow{2}{*}{ Jumlah } \\
\hline & & $\begin{array}{l}\text { Laki- } \\
\text { Laki }\end{array}$ & Perempuan & \\
\hline 1. & o-Bulan - 12 Bulan & 315 & 236 & 545 \\
\hline 2. & 13 Bulan -6 Tahun & 240 & 359 & 599 \\
\hline 3. & 7 Tahun - 12 Tahun & 307 & 411 & 718 \\
\hline 4. & $\begin{array}{l}13 \text { Tahun }-15 \\
\text { Tahun }\end{array}$ & 223 & 264 & 487 \\
\hline 5. & $\begin{array}{l}16 \text { Tahun }-18 \\
\text { Tahun }\end{array}$ & 252 & 249 & 501 \\
\hline 6. & $\begin{array}{l}19 \text { Tahun }-25 \\
\text { Tahun }\end{array}$ & 188 & 241 & 429 \\
\hline 7. & $\begin{array}{l}26 \text { Tahun }-35 \\
\text { Tahun }\end{array}$ & 210 & 742 & 952 \\
\hline 8. & $\begin{array}{l}36 \text { Tahun }-45 \\
\text { Tahun }\end{array}$ & 268 & 1233 & 1510 \\
\hline 9. & $\begin{array}{l}46 \text { Tahun }-50 \\
\text { Tahun }\end{array}$ & 260 & 234 & 495 \\
\hline 10. & $\begin{array}{l}51 \text { Tahun }-75 \\
\text { Tahun Ke atas }\end{array}$ & 203 & 390 & 593 \\
\hline
\end{tabular}

*Sumber : Propil Desa Batunyala

Dari tabel diatas, dari setiap golongan umur ratarata menunjukkan jumlah perempuan jauh lebih banyak dari pada laki-laki

Tabel 2

Kepadatan Penduduk Desa Batunyala

\begin{tabular}{|l|l|l|}
\hline No. & Keterangan & Jumlah \\
\hline 1. & Laki-laki & 2466 jiwa \\
\hline 2. & Perempuan & 4363 jiwa \\
\hline 3. & Jumlah & 6829 jiwa \\
\hline 4. & Luas Wilayah & 918,51 jiwa \\
\hline \multicolumn{2}{|c|}{ * Sumber : Profil Desa Batunyala }
\end{tabular}

Tabel 3

Tingkat Pendidikan Penduduk Desa Batunyala

\begin{tabular}{|l|l|l|l|l|}
\hline No & Pendidikan & $\begin{array}{l}\text { Laki- } \\
\text { Laki }\end{array}$ & $\begin{array}{l}\text { Peremp } \\
\text { uan }\end{array}$ & Jumlah \\
\hline \multirow{4}{*}{$\begin{array}{l}\text { Tamaat Pend. } \\
\text { Umum }\end{array}$} & & & \\
\cline { 2 - 5 } & a. SD & 830 & 843 & 1673 \\
\hline & b. SLTP & 301 & 426 & 726 \\
\hline & c. SLTA & 250 & 202 & 452 \\
\hline & d. Akademi & - & - & - \\
\hline & e. Diploma & 19 & 3 & 22 \\
\hline $\begin{array}{l}\text { f. Universita } \\
\text { s / PT }\end{array}$ & 5 & 8 & 13 \\
\hline & $\begin{array}{l}\text { Tamat Pend } \\
\text { Khusus }\end{array}$ & & \\
\hline
\end{tabular}

${ }^{*}$ Sumber : Profil Desa Batunyala

a) Mata pencaharian penduduk

Data penduduk desa batunyala, jika dilihat menurut jenis mata pencaharian adalah sebagai berikut :

Tabel 4

Jenis Pekerjaan Penduduk Desa Batunyala

\begin{tabular}{|l|l|l|}
\hline No. & Jenis Pekerjaan & Jumlah \\
\hline 1. & $\begin{array}{l}\text { Pegawai Negeri Sipil } \\
\text { (PNS) }\end{array}$ & 44 jiwa \\
\hline 2. & Wirasswasta & 10 jiwa \\
\hline 3. & Petani & 4.028 jiwa \\
\hline 4. & Buruh Tani & 1.667 jiwa \\
\hline $5 \cdot$ & TNI/POLRI & 5 jiwa \\
\hline 6. & Pekerjaan tidak tentu & $1.80 \quad$ Jiwa \\
\hline \multicolumn{2}{|c|}{ *Sumber : Profil desa Batunyala } \\
\hline
\end{tabular}

b) Kehidupan Beragama dan Struktur Sosial
Penduduk di Desa ini mayoritas beragama Islam, bahkan bisa dibilang $100 \%$ beragama Islam, bisa dilihat dalam tebal berikut ini:

Tabel 5

Penduduk menurut Agama yang dianut

\begin{tabular}{|l|l|l|l|l|}
\hline \multirow{2}{*}{ No } & \multirow{2}{*}{ AGAMA } & \multicolumn{3}{|l|}{ Jumlah penganut (Orang) } \\
\cline { 3 - 5 } & & $\begin{array}{l}\text { Laki- } \\
\text { Laki }\end{array}$ & $\begin{array}{l}\text { Perempua } \\
\text { n }\end{array}$ & Jumlah \\
\hline 1 & Islam & 2466 & 4363 & 6829 \\
\hline 2 & Kristen & - & - & - \\
\hline 3 & Katolik & - & - & - \\
\hline 4 & Hindu & - & - & - \\
\hline 5 & Budha & - & - & - \\
\hline
\end{tabular}

${ }^{*}$ Sumber : Profil Desa Batunyala

Berdasarkan tabel yang di atas jelas terlihat bahwa penduduk desa Batunyala semua penduduknya beragama Islam, dan tidak ada satupun yang menganut agama lain.

\section{HASIL DAN PEMBAHASAN}

\section{Prosesi Pelaksanaan Adat Merariq Di Masyarakat}

Dari beragam praktek perkawinan dikalangan masyarakat sasak yang pelaksanaannya selalu melalui suatu proses adat secara hirarki dan sistematis. berikut ini penjelasan tentang tahapan-tahapan dalam pelaksanaan upacara perkawinan adat sasak yaitu :

a) Merariq

Merariq adalah proses perkawinan yang dilakukan dengan cara calon suami membawa calon isterinya ke rumah keluarga atau kerbat dekat pihak laki-laki kemudian dari rumah keluarga kerabat laki-laki tersebut sang calon istri diajak ke rumah calon pengantin laki-laki.

b) Melaksanakan Sejati/Selabar

Mesejati ini merupakan laporan kepada alat atau perangkat desa (Kepala desa atau Kadus), bahwa di desanya telah ada orang yang melakukan merariq. Sedangkan melakukan selabar berarti menyebarkan kepada masyarakat tentang merariq nya seorang laki-laki dengan seorang perempuan. Dalam bahasa Sasak, Selabar artinya pengabaran berita kepada masyarakat luas tentang terjadinya suatu hal. Pihak laki-lakl harus melapor kejadian merariq tersebut kepada kepala dusun dimana perempuan itu tinggal.

Adapun pihak-pihak yang melakukan besejati yaitu Pihak keluarga pengantin perempuan memberitahukan atau melaporkan kepada aparat desa setempat. Keluaraga dari pihak pengantin memberitahukan kepada aparat desa untuk memastikan bahwa anak-anaknya benar-benar menikah dan meminta agar aparat desa segera mengurus dan mencari tahu tentang kebenaran kabar pernikahan tersebut sehingga pihak keluarga merasa tenang dan tidak khawatir.

c) Mbait Wali (Mengambil wali)

Adat mbait wali yakni meminta wali kepada orang tua pihak perempuan untuk disahkan sebagai suami isteri secara Agama Islam, ini dilakukan agar perkawinan tidak melanggar hukum Islam, Dalam proses mbait wali dilakukan pembicaraan (tawar menawar) tentang pisuke 
(uang tebusan/jaminan dari pihak laki-laki kepada pihak wanita) dan mahar (maskawin).

d) Nikahang (Menikah)

Ngawinan dalam bahasa sasak artinya menikahkan. Merupakan prosesi yang paling sakral, yakni kedua calon mempelai akan melalui porses ijab kabul dan disini pasangan akan resmi dan sah menjadi pasangan suami isteri secara hukum Islam dan hukum Pemerintah.

e) Membait Janji (mengambil janji)

Sesudah pernikahan secara agama dilaksanakan, barulah acara perundinmgan dilakukan sebagai kelanjutan prosese menentukan waktu untuk mengadakan penyelesaian adat yang dinakaman ajaikranma atau sorong serah yang merupakan puncak adat dari seluruh perkawinan dan ini bersifat menentukan

f) Ajikrama (Sorong Serah)

Dalam upacara ini merupakan inti dari adat perkawinan, dan dilakukan oleh kedua belah pihak, yaitu pihak laki-laki mengirim rombongan yang terdiri dari dua puluh samapi tiga puluh dengan membawa harta benda yang akan diserahkan kepada pihak perempuan. Rombongan ini dinamakan penyorong, sedangkan keluarga pihak perempuan yang akan menerima penyerahan itu dinakmakan penanggap atau penerima.

g) Nyongkolan

Upacara ini dilakukan setelah upacara adat sorong serah selesai, lalu disusul dengan arakan kedua mempelai, yang nantinya diperkenalkan kepada keluarga pihak perempuan.

h) Balik Lampak Nae

Upacara ini dilakukan setelah dua atau tiga hari setelah upacara nyongkolan selesai, kedua pengantin akan datang lagi ke rumah orang tua perempuan dengan rombongan terbatas, dengan tidak memakai upacara, karena kedatangannya itu semata-mata sebagai keluarga dalam kehidupan sehari-hari. Biasanya kedua pengantin akan menginap beberapa malam, sebagai pengenalan pebi pengantin laki-laki terhadap sanak keluarga yang perempuan.

\section{Makna Tradisi Merariq Bagi Masyarakat Batunyala}

Tradisi merariq dipengaruhi oleh pemikiranpemikiran masyarakat itu sendiri, sehingga budaya merariq tersebut menjadi sebuah tradisi yang diyakini dan dilaksanakan menjadi bagian dari adat perkawinan di Lombok Tengah terutama di desa Batunyala tersebut. Seperti yang dikemukakan oleh Koentjaraningrat dalam (Setiadi, 2006:28-30) bahwa kebudayaan tersebut menunjukkan wujud ide dari kebudayaan, sifatnya abstrak, tidak dapat diraba, dipegang, ataupun difoto, dan tempatnya ada dialam pikiran warga masyarakat di mana kebudayaan yang bersangkutan hidup.

Masyarakat yang melakukan merariq harus menjalankan berbagai rangkaian dan ritual atau tradisi yang sudah diyakini oleh masyarakat yang memiliki makna tertentu dan diyakini serta dapat dijadikan sebagai pegangan dalam menjalani kehidupan. Setiap prosesi adat yang dijalankan dianggap mempunyai makna tersendiri oleh masyarakat, mulai dari awal melarikan gadis sampai dengan upacara terakhir yang masing-masing memiliki makna dan tujuan. Berikut makna dalam tradisi merariq menurut masyarakat sebagai berikut :

1) Merariq mempunyai nilai untuk mengistimewakan perempuan

Dalam tradisi merariq ini dianggap sebagai nilai yang "mengistimewakan" seorang perempuan dimana posisi sosial perempuan ditempatkan dalam strata sosial yang lebih tinggi dari pada laki-laki dalam kehidupan sosial.

Penjelasan ini juga dibenarkan oleh Bapak Supriady (seorang yang dijadikan pembayun dalam proses adat sorong serah dalam merariq) :

"Tetun dengan nine no istimewe sengaq mut yaq lalo paling nine harus bejauq senjate, ye isiqte bejage-jage sengaq laeq mut te dait isiq keluargen saq nine bait anakn te empuk padek siq dengan loeq. Ye ampok dengan merariq no kemalem dait teboyaang jelo saq solah adekn saq mulus pas yaq perariqang calon seninen no”.

"Benar memang perempuan itu istimewa kalau dilarikan karena ketika melarikanpun butuh keberanian makanya kita membawa senjata apabila kita akan melarikan seorang gadis soalnya kalau sampai ketahuan oleh keluarga yang perempuan kami mengambil anaknya maka akan dipukul oleh keluarganya. Itulah yang menyebabkan merariq itu dilakukan pada malam hari dan biasanya nanti sebelum melarikan gadis, orang tua akan mencarikan waktu yang bagus agar merariq bisa berjalan mulus.

Dari penjelasan subyek di atas, dari zaman dulu perempuan yang dilarikan itu adalah perempuan yang dianggap istimewa karena ketika akan melarikan harus dilarikan pada malam hari dan sampai membawa senjata untuk berjaga-jaga karena apabila ketahuan oleh keluarga yang perempuan laki-laki tersebut akan dipukul dan anaknya akan diambil oleh orang tuanya. Itulah yang menyebabkan merariq harus dilakukan di malam hari biar tidak mudah untuk diketahui oleh orang tuanya dan apabila ada yang melakukan merariq di siang hari maka akan dikenakan denda dan denda ini biasanya akan dikeluarkan sewaktu upacara sorong serah $^{1}$ yang setelah semuanya terlaksana. Akan tetapi di zaman sekarang denda itu sudah bukan menjadi penghalang bagi mereka untuk melakukan merariq di siang hari, karena banyak yang sudah tidak mempermasalahkan denda tersebut, dan zaman yang sekarang juga sudah tidak membawa senjata ketika melarikan gadis, dan melarikan gadis juga tidak harus lewat rumahnya, karena banyak pemuda-pemuda sekarang melakukan merariq dari sekolah atau tempat rekreasi dengan cara janjian terlebih dahulu seperti yang dikatakan oleh bapak Ir. Haryanto (selaku kepala desa Batunyala):

"Adat merariq yang sekarang ada pergeseran budaya karena adanya kemajuan tekhnologi dan pendatang yang menyebabkan adat ini sedikit bergeser akan tetapi adat merariq masih tetap dilaksanakan"

Dari penjelasan informan tersebut adat merariq yang sekarang memang sudah mengalami pergseseran 
karena seiring dengan kemajuan tekhnologi kemudian hubungan-hubungan sosial sudah majemuk, nilai itu sekarang sudah tidak dipegang lagi oleh masyarakat atau pemuda sekarang, mereka melarikan gadis belum tentu tahu maknanya, sehingga banyak yang dilarikan sepulang sekolah, atau di tempat-tempat lainnya, padahal dulu gadis itu harus dilarikan pada malam hari dan di ambil dirumahnya.

2) Merariq memiliki pesan sosial

Struktur sosial yang ada pada masyarakat yang mengharuskan setiap individu-individu di dalam komunitasnya menempatkan seorang perempuan sebagai individu yang diposisikan ke dalam kelas sosial yang lebih dari pada laki-laki dimana perempuan harus dihormati, dan jika ingin menikahinya harus juga melalui perjuangan, dan dari pejuangan itulah akan dilihat bagaimana keseriusan seorang laki-laki terhadap perempuan yang ingin dinikahinya itu. Seperti yang dikatakan oleh Ibu Rohaini, S.Pd kepada peneliti :

"Adat merariq memang sudah menjadi tradisi di desa ini dan setiap ada laki-laki yang ingin menikahi perempuan maka harus dilarikan dahulu, dan adat melarikan perempuan itu menunjukkan penghormatan terhadap keluarga yang perempuan".

Dari penjelasan informan di atas, tradisi merariq yang ada di desa Batunyala ini adalah merupakan adat yang harus diikuti oleh masyarakat yang dimana proses dalam melarikan gadis itu mempunyai makna untuk memberikan penghormatan kepada keluarga yang perempuan, karena orang tua dari pihak perempuan akan merasa tersinggung apabila ada laki-laki yang melamar anaknya. Jadi merariq mungkin bagi masyarakat yang tidak menggunakan adat ini dianggap hal yang negatif seperti yang kita ketahui di dalam masyarakat lain yang tidak menggunakan tradisi ini, seseorang yang membawa lari perempuan untuk menikah biasanya apabila mereka tidak disetujui oleh kelurga yang perempuan, tapi lain halnya dengan yang ada di Lombok Tengah yaitu di desa Batunyala orang tua akan tersinggung apabila anaknya dilamar. Seperti yang dikatakan oleh Amaq Man (Suhaili) :

"Mun ara' dengan mame ya' lamar anak ke timaqn jari pegawe trus timaqn selese kuliahn ndek yaq bengn langsung, seharusn dengan sak wah sekolah wah pahamn tentang adat saq eleq te trus kembeq ndek ikuti adat, dendeq saq mentang-mentang wah begawean lapu trus banggen teparan yaq bengn langsung. Endah lain idapn mun yak te endeng anak te saq nine, wah biase siq adat tepaling doang leq te. Jari ye taoq te engat ntan tetu-tetu isiqn mele leq anak ite. “

"Kalau misalnya ada laki-laki yang akan melamar anak saya meskipun dia itu sudah berpendidikan tinggi, saya tidak akan begitu saja memberikan izin justru karena dia berpendidikan tinggi seharusnya sudah paham juga tentang adat yang ada, dan dengan alasan apa tidak mau mengikuti dan jangan dikira dengan sudah bekerja akan dengan mudah untuk memberikan anak gadis langsung, dan akan lain rasanya jika anak perempuan kita itu diminta karena sudah terbiasa dengan adat merariq, jadi dari merariq bisa dilihat perjuangan dia yang benar-benar ingin menikah dengan anak saya."

Subyek di atas tidak setuju kalau anak perempuannya diambil karena sudah terbiasa dengan merariq yang sudah lama dan menjadi adat di desa Batunyala dan proses melarikan yang dilakukan oleh laki-laki ketika mengambil anak perempuan mereka dan itu merupakan bukti keseriusan dan perjuangan yang dilakukan dari laki-laki tersebut. Dengan melarikan akan dianggap sebagai sesuatu yang luar biasa dari pada melamar.

3) Merariq mengajarkan untuk saling menghargai dan bersyukur

Bahwa di dalam kehidupan bermasyarakat hendaknya saling menghargai dan tetap bersyukur bersyukur atas segala kemudahan dan kelancaran serta karunia yang diberikan oleh Allah SWT, dan hal tersebut

Dalam acara raosan pisuke, keluarga laki -laki dan perempuan bertemu untuk menghasilkan kesepakatan bersama bahwa berapa yang harus diberikan pihak laki-laki kepada pihak keluarga yang perempuan yaitu mengenai uang tebusan atau barang yang menjadi maskawin calon pengantin perempuan.

4) Merariq memiliki pesan untuk mendidik

Adat merariq merupakan budaya perkawinan masyarakat karena makna budaya merariq banyak mengandung nilai-nilai pendidikan yang dapat dijadikan pegangan hidup dalam kehidupan bermasyarakat. Hal ini dapat dilihat dari setiap rangkaian prosesi adat merariq yang dilakukan oleh masyarakat. dan acara begawe yang dilakukan oleh masyarakat seperti yang dikatakan oleh Bapak Fathurrahman :

"Raosan pisuke ne kan keluargen saq mame kance nine bdait pire kepeng siqn tebeng, jari wah jari pengraosn keluarge saq mame kance nine leq acara nike".

Raosan pisuke ini merupakan dimana keluarga yang perempuan dan laki-laki bertemu untuk membicarakan berapa uang yang akan dikasi, jadi dalam acara ini untuk memperoleh kesepakatan antara kedua belah pihak keluarga.

Dalam acara raosan pisuke, keluarga laki -laki dan perempuan bertemu untuk menghasilkan kesepakatan bersama bahwa berapa yang harus diberikan pihak laki-laki kepada pihak keluarga yang perempuan yaitu mengenai uang tebusan atau barang yang menjadi maskawin calon pengantin perempuan.

5) Merariq memiliki Pesan moral

Dari adat merariq ini adapun pesan-pesan moral yang dapat di ambil bisa dilihat dari masyarakat yang senantiasa menumbuhkan sikap saling menghargai melalui sikap yang ditunjukkan di dalam kehidupan bermasyarakat. Tradisi tersebut terlihat dari bagaimana masyarakat ketika mulai mempersiapkan diri untuk melaksanakan ritual adat perkawinan, yakni persiapan dalam upacara sorong serah yang di dalam upacara tersebut kedua pihak keluarga perempuan dan laki-laki dalam membicarakan pisuke yaitu berupa uang tebusan atau barang yang akan diberikan kepada pihak keluarga perempuan.

6) Merariq memiliki sikap pemberani dan betanggung jawab 
Sikap pemberani dan bertanggung jawab yang terscermin dari laki-laki yang melaksanakan tradisi merariq. Perjuangan yang dilakukan oleh seorang laki-laki untuk dapat meminang gadis tidaklah mudah. Hal ini mencerminkan bahwa untuk memperoleh sesuatu yang diinginkan dibutuhkan keberanian serta tanggung jawab terhadap setiap tindakan yang dilakukan.

\section{Faktor Yang Menyebabkan Terjadinya Merariq Pada Masyarakat Batunyala}

Faktor yang menyebabkan masih terjadinya adat merariq sampai sekarang adalah karena adanya faktor-faktor sebagai berikut:

1. Faktor Adat

Merariq yang masih terjadi di desa Batunyala ini merupakan prosesi adat yang wajib dilakukan oleh setiap masyarakat yang akan melangsungkan pernikahan, dan prosesi tersebut merupakan tindakan yang dilakukan secara turun temurun. Seperti yang sudah dikatakan oleh informan sebelumnya diatas mereka melakukan merariq karena adat, dan dalam melakukan merariq ini tidak lebih hanya sebagai bentuk kecintaan mereka untuk melestarikan adat istiadat yang sudah ada. Seperti yang dikatakan oleh Aditya Juniarahman kepada peneliti :

"Saya merariq karena adat di lingkungan saya seperti ini adanya, dari saya kecil sampai sekarang adat melarikan yang banyak dilakukan oleh masyarakat disini, disamping itu juga tidak ada laki-laki yang kalau menikah akan melamar perempuan, yang ada perempuan akan dibawa lari dan disembunyikan jauh-jauh dari keluarganya. Dan itupun yang saya lakukan kemarin dengan membawa lari istri saya dan kami sembunyi di rumah keluarga saya yang ada di Lombok Timur."

Dari yang diungkapkan oleh subyek bahwa subyek melakukan merariq karena mengikuti adat yang ada di lingkungannya, dimana adat tersebut sudah dari dulu dan sampai sekarang masih dilakukan.

\section{Faktor Orang tua}

Masyarakat juga memandang bahwa sistem merariq lebih sopan dan bijaksana apabila anak gadisnya dibawa lari, dan orang tua akan lebih mengerti kalau anak gadisnya dibawa lari dari pada dipinang. Dalam hal ini orang tua sangatlah berpengaruh di dalam proses merariq, karena bagaimanapun juga restu orang tua adalah yang paling utama untuk kebahagiaan calon mempelai nantinya.

Seperti yang dikatakan oleh Ibu Rohaini, S.Pd kepada peneliti :

"Adat merariq ini memang sudah menjadi tradisi di desa ini dan setiap ada laki-laki yang ingin menikahi perempuan maka harus dilarikan dahulu, dan adat melarikan perempuan itu menunjukkan penghormatan terhadap keluarga yang perempuan".

Berdasarkan hasil wawancara di atas, bahwa apabila seorang laki-laki ingin menikahi seorang perempuan maka laki-laki tersebut harus mengikuti adat yang ada di desa Batunyala ini yakni dengan membawa lari perempuan tersebut dari rumah orang tuanya, dan kegiatan melarikan perempuan tersebut mempunyai makna yaitu menunjukkan penghormatan kepada keluarga perempuan, karena apabila perempuan tersebut dilamar maka akan memberikan ketersinggungan terhadap orang tua dan keluarga perempuan, dan oleh karena itu kegiatan melarikan yang dilakukan oleh seorang laki-laki akan dianggap lebih sopan dari pada laki-laki melamar perempuan tersebut.

\section{Faktor Agama}

Dalam adat merariq yang dilakukan oleh masyarakat, ajaran agama tetap dijalankan untuk menyelesaikan tradisi merariq tersebut. Dalam hal ini, adapun yang dikatakan oleh Bapak H. Ridwan, (tokoh agama di desa Batunyala) beliau mengatakan :

"Jika kita melihat di dalam ajaran agama kalau sudah sama suka harus segera dikawinkan, tapi hal itu banyak dipungkiri oleh masyarakat kita sekarang memang banyak yang mengatakan untuk mendahulukan agama dulu, akan tetapi pada kenyataannya mereka tidak mau melakukan hukum agama sebelum selesai hukum adat maskawinnnya itu, dan apabila proses adat maskawinnya sudah disepakati dan dibayar barulah proses agama dilakukan dengan menikahkan kedua calon mempelai."

Dari penjelasan tokoh agama di atas, bahwa di dalam melakukan adat merariq, sering dipersoalkan adalah masalah pisuke ${ }^{2}$. Seperti yang sudah ungkapkan oleh tokoh agama di atas, banyak masyarakat yang memang sebelumnya mengatakan akan mendahulukan ajaran agama dahulu akan tetapi hal tersebut ternyata banyak dipungkiri oleh masyarakat, karena dari pihak calon mempelai perempuan tidak akan memberikan wali begitu saja sebelum adanya kesepakatan

mengenai adat pisuke tersebut atau berapa mas kawin yang akan diberikan dari pihak keluarga calon mempelai laki-laki.

\section{Faktor Ekonomi (Biaya)}

Dalam hal ini terjadinya merariq juga hampir berlanjut sampai kepada aspek biaya, karena biasanya banyak juga laki-laki yang membawa lari anak gadis dan dia belum mempunyai pekerjaan atau masih mempunyai penghasilan yang minim, dan ini yang membuat mereka melakukan merariq dan mereka beranggapan bahwa dengan merariq akan meringankan biaya perkawinan dan untuk menghindari adanya mas kawin yang berlebihan.

5. Faktor dari kemauan Perempuan

Disamping karena adat, kemauan dari perempuan juga merupakan faktor yang menyebabkan merariq ini masih dilakukan oleh masyarakat, karena tanpa dari adanya kemauan yang perempuan maka merariq tidak akan bisa terjadi. Seperti misalnya perempuan yang dari daerah lain, maka akan memilih untuk tidak dilarikan karena mengikuti adat dimana perempuan itu tinggal, karena di dalam masyarakat Islam pun, masih terdapat juga beberapa kelompok-kelompok yang melakukan perkawinan dengan berbagai tradisi yang sangat beragam antara tradisi daerah yang satu dengan yang lainnya. (Falah, 2010: 17). Seperti yang dikatakan oleh Dedy Sukarnayadi : 
"Saya menikah dengan orang sumbawa, jadi saya juga harus mengikuti proses adat yang ada di sumbawa, disana ketika mau menikah dengan seorang wanita haruslah dengan cara dilamar, jadi saya tidak mungkin membawa lari istri saya karena adatnya disana tidak sama dengan disini, dan keluarganya juga meminta agar anaknya dilamar"

Subyek tidak melarikan calon istrinya tetapi subyek melamar karena ingin mengikuti adat dari isterinya, dan ini juga karena keluarga dari pihak yang perempuan yang tidak mau anaknya dilarikan. Hal ini menunjukkan lain daerah maka lain pula tradisinya, karena setiap daerah memiliki adat istiadat yang berbeda-beda, dan itu adalah suatu kewajiban untuk saling menghormati adat dari masing-masing daerah, agar tidak saling merugikan. Jadi kegiatan melamar bisa dilakukan apabila perempuan tersebut berasal dari daerah lain yang tidak menggunakan adat merariq.

Jadi jika seorang laki-laki ingin membawa lari seorang perempuan, tetapi kalau perempuan itu tidak mau maka merariq tidak bisa dilakukan, karena bagaimanapun juga merariq merupakan kesepakatan antara kedua calon mempelai laki-laki dan perempuan. Subyek tidak melarikan calon istrinya tetapi subyek melamar karena ingin mengikuti adat dari isterinya, dan ini juga karena keluarga dari pihak yang perempuan yang tidak mau anaknya dilarikan. Hal ini menunjukkan lain daerah maka lain pula tradisinya, karena setiap daerah memiliki adat istiadat yang berbeda-beda, dan itu adalah suatu kewajiban untuk saling menghormati adat dari masing-masing daerah, agar tidak saling merugikan. Jadi kegiatan melamar bisa dilakukan apabila perempuan tersebut berasal dari daerah lain yang tidak menggunakan adat merariq.

\section{SIMPULAN DAN SARAN}

\section{Kesimpulan}

Di dalam prosesi pelaksanaan tradisi merariq, banyak prosesi-prosesi atau upacara-upacara adat yang harus dilakukan oleh masyarakat yang diyakini mempunyai berbagai macam makna yang dapat dijadikan sebgai pegangan hidup yaitu didahulukan dengan proses Merariq, Sejati Selabar, Mbait wali (mengambil wali), Nikahang (menikahkan), Mbait Janji (Mengambil janji), Aji Krama (sorong serah), Nyongkolan, dan Balik Lampak Nae.

Dari rangkaian adat yang dijalan oleh masyarakat di atas, adapun makna yang dapat diambil dari upacara-upacara adat yang dilakukan oleh masyarakat diantaranya yaitu: Mempunyai nilai untuk mengistimewakan perempuan, yaitu posisi sosial perempuan ditempatkan dalam strata sosial yang lebih tinggi dibanding dengan laki-laki dalam kehidupan sosial; Memiliki pesan sosial, yaitu menempatkan seorang perempuan lebih dari laki-laki karena itu perempuan harus dihormati; Memiliki pesan untuk saling menghargai dan bersyukur, karena di dalam kehidupan bermasyarakat manusia dituntun agar saling menghargai dengan yang lainnya serta untuk selalu bersyukur kepada Allah SWT; Memiliki pesan untuk mendidik, dimana dari setiap rangkain prosesi yang dijalankan mempunyai makna yang dapat diambil oleh masyarakat; Memiliki pesan moral, karena bisa kita lihat dari masyarakat yang masih menghargai tradisi yang sudah dari dulu dan masih mereka pertahankan samapi sekarang.; dan Menunjukkan sikap pemberani dan betanggung jawab yaitu ditunjukkan dari sikap seorang laki-laki yang membutuhkan keberanian dan perjuangan untuk mendapatkan perempuan yang ingin dinikahinya.

Faktor yang mempengaruhi tradisi merariq ini adalah Faktor adat, masyarakat menganggap tradisi ini adalah menjadi tradisi leluhurnya sehingga masyarakat tinggal mengikuti dan berusaha untuk dapat melestarikan adat yang sudah ada; Faktor Orang tua, karena orang tua menganggap melarikan lebih sopan dari pada anak perempuannya dilamar; Faktor Agama, karena di dalam agama islam kaum laki-laki akan menjadi pemimpin bagi kaum perempuan, dan hal tersebut berhubungan dengan makna laki-laki dalam melarikan gadis yaitu laki-laki tersebut kuat, pemberani dan bertanggung jawab di dalam keluarganya; Faktor Ekonomi (biaya), biasanya laki-laki yang membawa lari perempuan untuk meringankan biaya perkawinan terutama untuk menghindari mas kawin yang berlebihan dari keluarga yang perempuan; dan yang terakhir yakni Faktor dari kemauan perempuan, di dalam merariq ini tentunya ada kemauan dari yang perempuan untuk dilarikan, karena ada juga perempuan yang tidak mau dilarikan dan memilih untuk dilamar.

\section{Saran}

a) Dengan melihat perkembangan tekhnologi yang semakin maju, seharusnya orang tua lebih mengontrol lagi hape yang dipegang oleh anaknya, karena dengan begitu bisa mengurangi kemungkinan anaknya untuk melakukan merariq di tempat-tempat yang tidak seharusnya dilakukan. Kemudian di dalam melakukan upacara adat mbait wali, sebaiknya jangan terlalu mempersulit dari pihak keluarga laki-laki, hal seperti ini dapat menunda proses menikahkan, dan dalam meminta pisuke (uang tebusan, mas kawin) orang tua perempuan perlu melihat dari kemampuan yang laki-laki agar tidak menyulitkan keluarganya.

b) Agar makna dari tradisi merariq ini tidak berubah, seharusnya laki-laki yang ingin melarikan gadis sebaiknya tetap melewati rumah orang tua perempuan agar tidak terjadi anggapan negatif dari masyarakat yang apabila dibawa lari dari sekolah atau tempat rekreasi. Dan jika ingin menikah sebaiknya mempunyai pekerjaan dulu atau minimal sudah mempunyai penghasilan, supaya tidak menyulitkan orang tua ketika dimintai uang tebusan atau mas kawin oleh pihak keluarga perempuan.

\section{DAFTAR RUJUKAN}

Abdulsyani. 2002. Sosiologi : Skematika, Teori dan Terapan. Jakarta : PT Bumi Aksara

Abudullah, Irwan. 2006. Konstruksi dan reproduksi Kebudayaan. Yogyakarta: Putaka Belajar

Adji, Sution Usman. 2002. Kawin Lari Dan Kawin Antar Agama. Liberty : Yogyakarta

Ahmadi, Abu. 1982. Sosiologi Pendidikan. Cet ke IV. Surabaya : PT Bina Ilmu 
Alo Liliweri. 2002. Makna Budaya dalam Komunikasi Antar Budaya. Yogyakarta: Lkis

Amin, Ahmad, dkk. 1978. Adat Upacara Perkawinan Daerah Nusa Tenggara Barat. Jakarta : Balai Pustaka

Arikunto, Suharsimi. 2006. Prosedur Pendekatan Praktis, edisi revisi VI. Jakarta : Rineka Cipta Dengan Pemikiran

Bachtiar, Wardi. 2006. Sosiologi Klasik. Dari Comte hingga Parsons. Bandung: PT Remaja Rosdakarya

Bzn, Ter Haar. 1999. Asas-Asas Dan Susunan Hukum Adat. Jakarta : Pradnya Paramita.

Chair, Abdul. 1994. Pengantar Semantik. Jakarta : Rineka Cipta.

H. Sudirman, S.Pd. 2007. Gumi Sasak Dalam Sejarah. Lombok : Prima Guna

Hadikusuma, Hilman. 2003. Pengantar Ilmu Hukum Adat Indonesia. Bandung : Mandar maju.

Haryanto, Danny. 2011. Pengantar Sosiologi Dasar. Jakarta : PT. Prestasi Pustakarya

Haryanto, Sindung. 2012. Spektrum Teori Sosial Dari Klasik Hingga Postmodern. Yogyakarta : Ar-Ruzz Media.

Havilan, William dan R.G. Soekardjo. Antropolgi. Jakarta :

Erlangga

Jhon B. Thomson. 2004. Kritik ideologi Global teori sosial Kritis tentang Relasi Ideologi Dan Komunikasi Masa. Yogyakarta : IRCiSoD

Koentjaraningrat. 1980. Manusia Dan Kebudayaan di Indonesia. Jakarta : Djambatan

Koentjaraningrat. 1984 . Kebudayaan Dan Mentalis Pembangunan. Jakarta : PT Gramedia.

Maran, Rafael Ragan. 2007. Manusia Dan Kebudayaan Dalam Persfektif Ilmu Budaya Dasar . Jakarta : Rineka Cipta

Moleong, L.J. 2002. Metodologi Penelitian Kualitatif. Bandung: Remaja Rosdakarya.

2011. Metode Penelitian Kualitatif. Bandung: Remaja Rosdakarya.

Morissan. 2013. Teori komunikasi. Individu Hingga Massa. Jakarta: Kencana Prenada Media Group

Musaddat, Syaiful. 2011. Kamus Bahasa Sasak. Istilah Hukum dan Adat. NTB: Primaguna.

Noor, Arifin. 1999. ISD. Ilmu Sosial Dasar. Bandung : CV Pustaka Setia.

Poesponoto, Soebakti. 2001. Asas-Asas Dan Susunan Hukum Adat. Jakarta : Pradnya Paramita.

Ratna, Nyoman Kuthe. 2009. Penelitian Sastra : Teori, Metode, dan Tekhnik. Yogyakarta : Pustaka Belajar.

Saragih, Drajen. 1992. Hukum Perkawinan Adat Dan Undang-Undang Tentang Perkawinan Serta Peraturan Pelaksanaannya. Bandung : Tarsito

Setiadi, Elly. M . 2006. Ilmu Sosial Dan Budaya Dasar. Jakarta : Kencana Prenada Media Group .

Soejono Soekanto. 2003. Sosiologi Suatu Pengantar. Jakarta : Raja Grafindo Persada.

Soelaiman, Munandar. 1998. Dinamika Masyarakat Transisi. Yogyakarta: Pustaka Pelajar.

Sudarsono. 1991. Hukum Perkawinan Nasional. Jakarta : Penerbit PT. Rineke Cipta.

Sugiyono. 2010. Metode Penelitian Kuantitatif, Kualitatif dan $R \& D$. Bandung: Alfabeta.

Sution Usman Adji. 2002. Kawin Lari Dan Kawin Antar Agama. Yogyakarta.

Tutik, Titik Triwulan. 2006. Pengantar Hukum Perdata di Indonesia. Jakarta: Prestasi Pustaka

Troyo Supriyanto, Padil. 2010. Sosiologi Pendidikan. Malang : UIN Maliki Press

Van Dijk. 2006. Pengantar Hukum Adat Indonesia. Bandung : Mandar Maju.

Wulansari, Dewi. 2010. Hukum Adat Indonesia Suatu Pengantar. Bandung: PT Refika Aditama.

Yulianti, Yayuk \& Purnomo, Mangku. 2002. Sosiologi Jurnal:
Ali Akbarul Falah.2010. Pandangan Masyarakat Islam Terhadap Tradisi Mattunda Wenni Pammulang Dalam Perkawinan Adat Bugis. (Jurnal Hukum dan Syariah. Fakultas syariah. malang : Universitas Islam Negeri Maulana Malik Ibrahim. Volume 1, Nomor 1, Juni 2010).

Arnis Rachmadhani. 2011. Perkawinan Islam Wetu Telu Masyarakat Bayan Lombok Utara. (Jurnal Analisa Volume xviii, No. 01, Januari-Juni 2011).

Hardjo Sodarsono. 2012. Dalam Pemikiran Religius Dan Perwujudan Budaya Spritual Penghayatan Kepercayaan Kejawen (dalam Jurnal Kebudayaan Jawa Edisi 3 Th II 2007 ).

Haryanto, Joko Tri. 2012. Fenomena Perkawinan di Bawah Umur (dalam Jurnal Analisa Volume 19 No 01 Januari).

Macey \& Rokhman M.A. 2008. Keterkaitan Kajian Budaya dan Studi Sastra di Inggris: sebuah telaah singkat. (Jurnal Humaniora, Jurnal Budaya, Sastra, Dan Bahasa Fakultas Ilmu Budaya Universitas Gajah Mada, Volume 20, Nomor 1 Februari). 